\title{
Vliv polohy lokte a zápěstí na výsledky EMG - předběžné výsledky
}

\author{
Martin Kába ${ }^{1}$, Ilona Kačerová ${ }^{1}$ \\ ${ }_{1}$ Západočeská univerzita v Plzni, Fakulta strojní, Katedra průmyslového inženýrství a \\ managementu \\ Univerzitní 8, 306 14, Plzeň, Česká republika \\ kaba@kpv.zcu.cz \\ ikacerov@kpv.zcu.cz
}

\begin{abstract}
Anotace: Výzkum se zabývá hodnocením dopadu poloh horních končetin (lokte a zápěstí) na lokální svalovou zátěž horních končetin. Lokální svalová zátěž je měřena metodou integrované elektromyografie a následně vyhodnocena dle české legislativy. Jedná se o úvodní studii, která zpracovává prvotní výsledky experimentů.
\end{abstract}

\section{1 Úvod}

Pracovníci $v$ dnešní době čelí problému nemoci z povolání. Ta může být způsobena mnoha problémy a může být trvalá, nebo dočasná. Indispozice pracovníka je však nepř́ijemná jak pro něj, tak pro jeho zaměstnavatele. $V$ České republice bylo $v$ roce 2017 hlášeno 1370 nemocí z povolání 1117 pracovníků (551 žen a 566 mužů). Ve srovnání s rokem 2016 se celkový počet hlášených nemocí z povolání zvýšil o 73 (tj. 5,6 \%). V roce 2017 byli nejvíce postiženi pracovníci $v$ odvětvích „výroba motorových vozidel, přívěsů a návěsư“, „sociální péče a sociální péče“ a „ěžba a dobýváni““. Pracovníci ve výrobě motorových vozidel trpěli převážně přetížením končetin (155 případů) a profesionální dermatózou (16 případů). Nejčastěji hlášenou diagnózou je syndrom karpálního tunelu. Ten může být způsoben přetížením končetin (více než 320 hlášených prípadů) nebo vibracemi (více než 140 hlášených př́ipadů). [1] [2] Syndrom karpálního tunelu je suverénně nejčastější nemocí z povolání, se kterou se Ize u pracovníků setkat. Incidence tohoto onemocnění je udávána mezi 180 až 346 diagnostikovanými př́pady/100 000 obyvatel a rok. Ženy jsou v tomto prípadě postihovány zhruba 3x častěji než muži. [3]

Tento výzkum je zaměřen na problematiku lokální svalové zátěže $v$ oblasti rukou a předloktí. Lokální svalovou zátěž Ize hodnotit několika způsoby integrovanou elektromyografií nebo tenzometrickou a výpočetní metodou. Při výzkumu byla použita metoda integrované elektromyografie, která patří $k$ experimentálním vyšetřovacím metodám, které umožňují objektivní vyhodnocení neuromuskulární aktivity registrací bioelektrických potenciálů. Jedná se o neinvazivní metodu, která používá povrchové elektrody k zachycení signálů. [4] Výzkum se zabývá hodnocením dopadu poloh horních končetin (lokte a zápěstí) na lokální svalové zatížení. Jedná se o úvodní studii. 


\section{Metodika výzkumu}

Cílem výzkumu je hodnocení dopadu poloh horních končetin (lokte a zápěstí) na svalovém zatížení rukou a předloktí. Skupina mužů z České republiky ve věku 20 - 45 let byla měřena pomocí integrované elektromyografie, výsledky byly následně hodnoceny. Pracovní polohy v České republice jsou hodnoceny dle NV 361/2007 Sb., ty určují, zda je pracovní poloha príjatelná, podmíněně prǐjatelná a nepřijatelná. Nařízení vlády také určuje úhly lidského těla (např. rameno, loket atd.), ve kterých může pracovník pracovat. Výzkum byl zaměřen na dynamickou aktivitu a to ve čtyřech polohách lokte a čtyřech polohách zápěstí. Měření muži v ruce při pohybu drželi závaží $(0 \mathrm{~kg}, 2 \mathrm{~kg}, 4$ $\mathrm{kg}, 6 \mathrm{~kg}, 8 \mathrm{~kg}, 10 \mathrm{~kg} \vee$ prípadě pohybů lokte), $v$ případě pohybů zápěstí se jednalo o závaží $0 \mathrm{~kg}, 2 \mathrm{~kg}$ a $4 \mathrm{~kg}$. Účastníci měření vždy provedli jeden pohyb $\mathrm{s}$ jednou váhou. Úhel jejich pohybu byl měřen standardními goniometry. Výsledky z měření byly ve speciálním softwaru EMG Analyzer následně zpracovány a přepočteny na průměrnou Fmax.

\section{Měřicí zařízení}

$\checkmark$ dnešní době je známo a $v$ praxi využíváno několik typů elektromyografie. Od elektromyografie jehlové, při které jsou zaváděny jehličky do příslušných svalů až po elektromyografii povrchovou, kdy je sval měřen pomocí povrchových elektrod, které jsou nalepeny na příslušné místo. Výzkum byl proveden s měřicím prístrojem EMG Holter.

Tento prístroj byl vyvinut pro hodnocení lokální svalové zátěže horních končetin, konkrétně svalů ruky a předloktí. Přístroj umožňuje celosměnový záznam čtyř EMG signálů a pulsní frekvence. Během snímání EMG jsou ukládány integrální hodnoty a frekvence EMG signálů. EMG Holter obsahuje volný DC kanál pro připojení dalšího vnějšího modulu. Veškeré snímané hodnoty jsou ukládány do interní paměti prístroje, která umožňuje zaznamenávat data ze všech 4 kanálů až po dobu 17-ti hodin. Uložená data se po skončení měření přenáší do počítače $k$ dalšímu hodnocení. [4][5][6]

Samotný Holter je malá kompaktní jednotka z ocelového plechu tloušt'ky 0,8 $\mathrm{mm}$, která zajišt'uje vysokou odolnost a zároveň chrání elektroniku přístroje proti elektromagnetickému a elektrostatickému rušení. EMG svody jsou připojovány prostřednictvím konektorů, jejichž konstrukce zabraňuje samovolnému uvolňování a následnému přerušení snímání dat. Do jednoho svodu jsou instalovány dva EMG kanály, což snižuje počet kabelů a zjednodušuje tak samotné snímání. Pro snímání elektrických potenciálů jsou použity snímací elektrody. Elektrody jsou na kůži vybraného svalu připevněny pomocí jednorázových gelových elektrod. [6][7]

Výsledky z měření jsou ve speciálním softwaru EMG Analyzer následně zpracovány a hodnoceny dle NV 361/2007 Sb. 


\section{Průběh experimentu}

$\mathrm{Na}$ probandovu ruku jsou prìlepeny elektrody - 5 elektrod (dvě červené elektrody na extensor, dvě žluté elektrody na flexor a jedna zelená elektroda jako zemnící, která je prílepena na loketní kost). Probandi po připojení EMG Holteru namačkali na dynamometru Jamar Plus+ maximální svalovou sílu (Fmax), jedná se o sílu, kterou je vyšetřovaná osoba schopna dosáhnout při maximálním volním úsilí, které je vynakládané konkrétními svalovými skupinami. Poté proband postupuje dle plánu, nejprve je zkoumána pravá ruka - loket. Probandova ruka je $v$ neutrální poloze $0^{\circ}$, loket je poté ohnut do $-30^{\circ}$ a následně zpět do $0^{\circ}$. Tento pohyb je opakován se závažím $(0 \mathrm{~kg}, 2 \mathrm{~kg}$, $4 \mathrm{~kg}, 6 \mathrm{~kg}, 8 \mathrm{~kg}, 10 \mathrm{~kg}$ ). Poté ruka odpočívá a stejný pohyb je opakován $\mathrm{s}$ rukou levou. Následuje ohyb ruky z $0^{\circ}$ do $-60^{\circ}$ a zpět, vše se opakuje pro obě ruce a pro všechna závaží. Poté je měřen pohyb lokte $0^{\circ} a z ̌ ~+30^{\circ}$ a následně $0^{\circ} a z ̌+60^{\circ}$. Po změření všech úhlů lokte se všemi závažími je měřen pohyb zápěstí. Pohyb zápěstí je zkoumán následujícím způsobem, probandova ruka je položena do vhodné výšky, ruka se opírá o stůl, proband nejprve provádí pohyb s nulovým závažím, poté s $2 \mathrm{~kg}$ závažím a nakonec $\mathrm{s} 4 \mathrm{~kg}$ závažím. Nejprve je provedena extenze zápěstí (závaží je drženo nadhmatem), poté je zkoumána flexe zápěstí (závaží je drženo podhmatem), následně je zkoumána ulnární dukce zápěstí (závaží je opět drženo nadhmatem) a nakonec je proveden pohyb radiální dukce (závaží opět drženo nadhmatem). Ruce jsou během jednotlivých měření střídány. Zároveň jsou mezi měřeními 10 vteřinové pauzy. Po měření je proband odpojen od EMG Holteru.

\section{$5 \quad$ Zpracování dat}

Po ukončení měření jsou data uložena do přístroje a přetažena do počítače, kde jsou následně zpracována ve speciálním softwaru EMG Analyzer. Pohyby byly během měření ohraničeny markerem. Každý $z$ těchto pohybů je následně vyhodnocen jako průměrné \% Fmax. Průměrná svalová síla ( $\%$ Fmax) je síla, která je vyjádřena $v$ relativních hodnotách průměrnou směnovou časově váženou hodnotou \% Fmax v průměrné směně. [8] Prủměrná směnová časově vážená hodnota \% Fmax nemůže v průměrné osmihodinové směně překročit $30 \%$, tato hodnota je pro vyhodnocení brána jako stěžejní. [9] 


\section{Výsledky měření}

Obsahem této kapitoly jsou předběžné výsledky vyhodnocené jako průměrné hodnoty z osmi měřených probandů. Následující dvě podkapitoly podrobně znázorňují výsledky měření pohybů loktů a zápěstí.

\subsection{Vliv polohy lokte na výsledky EMG}

Následující tabulka zobrazuje výsledné průměrné hodnoty \% Fmax z měření pohybů loktů a to:

- loket $0--30^{\circ}$,

- loket $0--60^{\circ}$,

- loket $0-+30^{\circ}$,

- loket $0-+60^{\circ}$.

Tabulka 1 - Výsledky měření loktů

\begin{tabular}{|c|c|c|c|c|c|c|c|}
\hline & & Okg & $2 \mathrm{~kg}$ & $4 \mathrm{~kg}$ & $6 \mathrm{~kg}$ & $8 \mathrm{~kg}$ & $10 \mathrm{~kg}$ \\
\hline \multirow[t]{4}{*}{ Loket -30} & Extensor PR & 2,31 & 5,77 & 8,10 & 10,62 & 14,68 & 19,47 \\
\hline & Flexor PR & 0,75 & 4,88 & 8,14 & 10,93 & 14,92 & 22,05 \\
\hline & Extensor LR & 2,60 & 6,45 & 9,54 & 12,95 & 14,63 & 18,94 \\
\hline & Flexor LR & 1,62 & 7,20 & 11,01 & 15,95 & 21,69 & 26,52 \\
\hline \multirow[t]{4}{*}{ Loket -60} & Extensor PR & 2,34 & 4,67 & 7,74 & 11,62 & 16,11 & 18,50 \\
\hline & Flexor PR & 1,10 & 3,20 & 7,11 & 10,75 & 17,04 & 20,07 \\
\hline & Extensor LR & 2,73 & 6,89 & 10,92 & 12,85 & 16,96 & 19,99 \\
\hline & Flexor LR & 2,08 & 6,99 & 9,49 & 14,91 & 24,68 & 31,07 \\
\hline \multirow[t]{4}{*}{ Loket +30} & Extensor PR & 2,21 & 6,50 & 8,45 & 10,07 & 16,40 & 13,25 \\
\hline & Flexor PR & 1,33 & 4,26 & 8,36 & 12,71 & 16,40 & 21,15 \\
\hline & Extensor $L R$ & 2,58 & 8,09 & 9,91 & 11,37 & 13,78 & 21,03 \\
\hline & Flexor LR & 1,90 & 9,31 & 14,12 & 19,69 & 26,36 & 30,06 \\
\hline \multirow[t]{4}{*}{ Loket +60} & Extensor PR & 2,30 & 7,87 & 9,16 & 13,24 & 15,76 & 18,77 \\
\hline & Flexor PR & 1,25 & 6,61 & 11,16 & 15,89 & 19,19 & 27,48 \\
\hline & Extensor $L R$ & 3,07 & 6,82 & 8,54 & 11,64 & 16,67 & 20,15 \\
\hline & Flexor LR & 2,60 & 8,45 & 14,74 & 20,94 & 29,52 & 39,46 \\
\hline
\end{tabular}

Tabulka 1 jasně dokazuje, že se zvyšující váhou roste i průměrná \% Fmax. Pohyb loktů se závažím do $6 \mathrm{~kg}$ je z hlediska průměrné \% Fmax v pořádku $\checkmark$ celém rozsahu měřeného pohybu. Problém nastává $s 8 \mathrm{~kg}$ zátěží při úhlu lokte ve směru kladných hodnot, tzn. ve směru flexe (ohnutí) lokte. $S 10 \mathrm{~kg}$ zátěží nastává problém u všech měřených pohybů. Pro běžnou opakovanou práci jsou tyto pohyby $\mathrm{s} 10 \mathrm{~kg}$ zátěží nepríijatelné a $v$ některých zmíněných úhlech lokte dokonce již se zátěží $8 \mathrm{~kg}$. Ve většině případů jsou dle hodnot $v$ tabulce více zatížené flexorové svaly. To je dáno tím, že měřený pohyb 
probíhal vždy podhmatem, kde právě flexory přebírají většinu práce. $\checkmark$ prípadě, že by pohyb probíhal nadhmatem Ize $s$ velkou jistotou predikovat podobné nebo dokonce ještě horší výsledky u vyšších vah díky vyššímu objemu svalů flexorových na předloktí lidské ruky.

Zjednodušeně Ize říci, že práce se závažími více než $8 \mathrm{~kg} v$ těchto úhlech lokte by se na pracovištích neměla vyskytovat vůbec nebo se vyskytovat mohou, ale pouze $v$ prípadě zařazení pracovišt' do kategorie práce č. 3 , což má za následek povinné přestávky po dvou pracovních hodinách atd.

\subsection{Vliv polohy zápěstí na výsledky EMG}

Následující tabulka zobrazuje výsledné průměrné hodnoty \% Fmax z měření pohybů zápěstí a to:

- extenze,

- flexe,

- ulnární dukce (pohyb za malíkem),

- radiální dukce (pohyb za palcem).

Tabulka 2 - Výsledky měření zápěstí

\begin{tabular}{|l|c|c|c|c|}
\cline { 3 - 5 } \multicolumn{2}{c|}{} & $0 \mathrm{~kg}$ & $2 \mathrm{~kg}$ & $4 \mathrm{~kg}$ \\
\hline Extenze & Extensor PR & 6,80 & 13,46 & 15,58 \\
\hline \multirow{4}{*}{ Flexe } & Flexor PR & 6,63 & 11,08 & 16,57 \\
\cline { 2 - 5 } & Extensor LR & 4,75 & 15,88 & 20,71 \\
\cline { 2 - 5 } & Flexor LR & 7,55 & 15,57 & 22,09 \\
\hline \multirow{4}{*}{ UInární dukce (za malíkem) } & Extensor PR & 3,04 & 7,53 & 10,81 \\
\hline \multirow{4}{*}{ Radiální dukce (za palcem) } & Flexor PR & 5,26 & 9,13 & 12,27 \\
\cline { 2 - 5 } & Extensor LR & 4,88 & 8,21 & 9,79 \\
\cline { 2 - 5 } & Flexor LR & 5,41 & 6,74 & 10,83 \\
\hline & Flexor PR & 6,15 & 17,15 & 19,06 \\
\cline { 2 - 5 } & Extensor LR & 12,97 & 22,05 & 27,60 \\
\cline { 2 - 5 } & Flexor LR & 7,29 & 16,72 & 22,93 \\
\hline & Extensor PR & 4,92 & 18,34 & 23,91 \\
\cline { 2 - 5 } & Flexor PR & 7,71 & 9,20 & 17,41 \\
\cline { 2 - 5 } & Extensor LR & 7,38 & 9,33 & 11,67 \\
\cline { 2 - 5 } & Flexor LR & 6,51 & 10,49 & 11,16 \\
\cline { 2 - 5 } & & & &
\end{tabular}

Na rozdíl od měření různých poloh lokte se $v$ prrípadě měření poloh zápěstí rešily pouze maximální rozsahy těchto kloubů ve čtyřech směrech. Konkrétně se tedy jedná o extenzi, flexi, ulnární a radiální dukci. Prvním důvodem je omezený rozsah kloubu zápěstí především při úklonech směrem za malíkem a palcem. $Z$ tohoto důvodu není potřeba pohyb dělit na více částí. Druhým důvodem je složité odečitání hodnot natočení kloubu zápěstí. 
Dalším omezením je zvolená zátěž při vykonávaných pohybech. Zadané striktní pohyby se $6 \mathrm{~kg}$ zátěží zvládnou pouze velmi silní jedinci, takže se měření provádělo s $0 \mathrm{~kg}, 2 \mathrm{~kg}$ a $4 \mathrm{~kg}$ zátěží.

$Z$ hlediska vyhodnocení průměrných \% hodnot Fmax je označena jako riziková práce pouze zátěž $4 \mathrm{~kg}$ a vyšší. Zajímavé je porovnání ulnární a radiální dukce. Dle naměřených hodnot Ize jasně potvrdit, že pohyb ruky ve směru malíku (ulnární dukce) je podstatně náročnější než pohyb ruky za palcem (radiální dukce). Tento fakt Ize zohlednit při ergonomických úpravách pracovišt' a pracovních postupů tak, aby se tento pohyb vyskytoval co možná nejméně. Už od své podstaty je tento pohyb poměrně nepriirozený a naměřené výsledky to jen dokazují. Záměrně byl pro všechna měření vybrán nadhmat a to $z$ důvodu obvyklé drobné manuální práce, která probíhá nejčastěji tímto způsobem. $Z$ tohoto důvodu není vhodné porovnávat extenzi $s$ flexí, protože právě extenzory jsou prì pohybu zápěstí s nadhmatem více zatěžovány.

Jako jeden z hlavních výsledků tohoto výzkumu Ize označit práci s rukama $v$ poloze nadhmatem $\mathrm{s}$ minimálním úklonem do stran a zátěží do $4 \mathrm{~kg}$ jako práci nerizikovou. Vyšší zátěž nebo krajní polohy kloubů zápěstí jsou pro drobnou manuální práci nepřijatelné.

\section{Závěr}

Studie byla zaměřena na problematiku lokální svalové zátěže $v$ oblasti rukou a předloktí. Výzkum se zabýval hodnocením dopadu poloh horních končetin (lokte a zápěstí) na lokální svalové zatížení horní končetiny.

Při zkoumání vlivu polohy lokte na výsledky EMG se došlo $k$ závěru, že práce se závažími více než $8 \mathrm{~kg}$ v úhlech lokte $0-+60^{\circ}$ by se na pracovištích neměla vyskytovat vůbec. $V$ prípadě, že se tento typ práce $s$ těmito váhami vyskytuje, je třeba $s$ velkou pravděpodobností zařadit pracovišt' do kategorie práce č. 3 , což má za následek povinné přestávky po dvou pracovních hodinách atd., aby měli pracovníci čas na oddech.

Výsledné hodnoty $z$ náměrů poloh zápěstí označují práci s rukama v poloze nadhmatem s minimálním úklonem do stran a zátěží do $4 \mathrm{~kg}$ jako práci nerizikovou. Vyšší zátěž nebo krajní polohy kloubů zápěstí jsou pro drobnou manuální práci neprijiatelné. Podrobné výsledky měření loktů a zápěstí jsou obsaženy v kapitole 6.

\section{Poděkování}

Tento článek byl vytvořen za podpory interního grantu Západočeské univerzity číslo SGS-2018-031 s názvem Optimalizace parametrů udržitelného výrobního. 


\section{Použitá literatura}

[1] Nemoci z povolání v České republice [online] 2017, [cit. 28.8.2019] Dostupné z: http://www.szu.cz/uploads/NZP/Hlaseni_NzP_2017.pdf

[2] Nemoci z povolání v České republice [online] 2016, [cit. 28.8.2019] Dostupné z: http://www.szu.cz/uploads/NRNP/aktual_Hlaseni_NzP_2016.pdf

[3] Minks, E., Minksová, A., Brhel, P., Babičová, V. Profesionální syndrom karpálního tunelu. In: Neurologie pro praxi, 2014, vol. 15, no. 5, p. $234-$ 239.

[4] Elektromyografie (EMG) | Moje zdraví. Moje zdraví - péče o psychickou i fyzickou pohodu [online] 2001, [cit. 12.7.2019]. Dostupné z: https://www.mojezdravi.cz/vysetreni/elektromyografie-emg-1922.html

[5] EMG [online] [cit. 28.8.2019]. Dostupné z: https://www.kntb.cz/emg

[6] Elektromyografie (EMG) - Vitalion.cz. Vyšetření - databáze vyšetření Vitalion.cz [online] [cit. 20.8.2019].Dostupné z: https://vysetreni.vitalion.cz/elektromyografie/

[7] EMG Holter |Fyziologie práce. [online] 2018, [cit. 15.7.2019]. Dostupné z: http://fyziologie.getacentrum.cz/ke-stazeni/

[8] Krajská hygienická služba Hradec Králové - elearning. Posuzování lokální svaloví zátěže [online] [cit. 20.8.2019]. Dostupné z: http://www.khshk.cz/elearning/kurs5/222_posuzovn_lokln_svalov_zte.html

[9] Zákony pro lidi.cz Nařízení vlády č. 361/2007 Sb. [online] [cit. 25.8.2019]. Dostupné z: https://www.zakonyprolidi.cz/cs/2007-361 